\title{
Issues of gender pedagogy: teaching boys the masculinity (preschool childhood stage)
}

\author{
Ramziya Mardashova ${ }^{1, *}$, Tatyana Garnysheva ${ }^{1}$, Zemfira Sharafetdinova ${ }^{1}$, Elena \\ Konovalova $^{1}$, Gulnara Khakimova ${ }^{1}$, and Nailya Khakimova ${ }^{1}$ \\ ${ }^{1}$ Naberezhnye Chelny State Pedagogical University, 28, Nizametdinov str., 423806, Naberezhnye \\ Chelny, Russia
}

\begin{abstract}
The article deals with the issues of supporting and developing the gender identity of boys at the stage of preschool childhood. The authors argue that it is possible to form the socially determined ideas about males in boys and to teach them the gender behavior based on these ideas but it should be carried out at the stage of pre-school childhood. The article contains the material of the experiment including specially selected forms, methods and conditions for teaching boys the masculinity at a senior preschool age. The scientific novelty lies in the fact that the totality of the findings contains a solution to the problem: the special forms and methods of working with preschoolers used in teaching allowed us to form specific features of gender-role behavior at a pre-school age. The theoretical significance is that the study defines the components of gender identity (cognitive, emotional-personal, behavioral) and their content, and identifies the factors that contribute to the development of gender identity in boys. The practical significance of the study lies in the applied orientation of the findings that can be widely employed in the practice of pre-school educational organizations.
\end{abstract}

\section{Introduction}

The current reality is that the ongoing political, economic and social changes in society contribute to the formation of a new post-industrial civilization and a new information society. The changes involve the obvious changes in the traditional social attitudes of the position and role of men and women in society. Today, the process of social leveling is going quite fast. It is characterized by the fact that men and women acquire similar features that are shown in behavior, in profession and lifestyle in general.

The ongoing socio-cultural transformations in the status of the sexes indicate that under the conditions of the changes in the gender-role stratification of society, the gender factor is the most important component in the studies of social and humanitarian sciences, including pedagogical sciences. The latter should include gender pedagogy. Gender pedagogy should set and solve the problems of gender education of the younger generation, recognizing that the current socio-cultural background changes the psychological stereotypes. This involves negative gender-role socialization and results in the partial or complete loss of true

* Corresponding author: ngpu.nis@gmail.com 
masculine qualities in boys and feminine qualities in girls. The central objectives of gender pedagogy are teaching children and young people the socially determined ideas about men and women and educating them about gender behavior.

Despite the fact that there are numerous Russian and foreign studies in the field of gender pedagogy [1], it should be recognized that there is no holistic scientific concept of gender education of children of early and preschool age [2]. The lack of such a concept does not allow us to fully solve the problems of pre-school education, taking into account the gender differences of pre-school children. In the light of the above, the studies of the issues of preschool children education with a gender approach that involves forming and developing both female and male models of sexual identification and self-realization are of great importance. Given this fact, we consider one of the issues. Its choice has determined the purpose of the study - to identify and experimentally prove the effectiveness of teaching pre-school boys the masculinity using specially selected forms, methods and conditions.

\section{Materials and Methods}

The theoretical and methodological basis of the study is made up of the works on the role of men and women in the development of society (N.G. Chernyshevsky [3], V.S. Solovyov [4], N.A. Berdyaev [5], etc.); foreign and Russian theories of development and gender identification of the individual (Burn S.M. [6], Ward A.Z. [ibid.], Flandrin J.-L. [7], Maccoby E.E. [8], Jacklin C.N. [ibid.], T.K. Antonova [2], V. Vdovyuk [1], S. Rykov [ibid.], etc.); theoretical and practical studies of the issues of teaching pre-school children the gender identity (M.A. Radzivilova [9], N.E. Tatarintseva [10], A.M. Shchetinina [11], etc.).

The purpose of the study has been achieved within the framework of methodological approaches: the cultural approach (V.S. Bibler, E.V. Bondarevskaya, L.V. Kolomiychenko, I.S. Kon, etc.); the activity approach (L.S. Vygotsky, A.N. Leontyev, S.L. Rubinstein, D.B. Elkonin, L.I. Bozhovich, etc.); the environment approach (K.D. Ushinsky, S.T. Shatsky, A.S. Makarenko, V.A. Sukhomlinsky, V.G. Bocharova, A.V. Mudrik, etc.). The methodological reference point in the study is the gender approach. We share the point of view of E.N. Kamenskaya, “... the gender approach in pedagogy is a methodological orientation in pedagogical activity that allows ensuring and supporting the processes of gender self-knowledge, self-building and self-realization of the child's personality, the development of the unique personality through a system of interrelated concepts, ideas and methods of actions. ..." [12].

The following methods have been used in the study: analysis of psychological, pedagogical, and socio-cultural literature, classification, comparison, generalization, systematization, experiment, observation, methods of mathematical statistics.

\section{Results}

Before considering the ways to achieve the purpose of the study we will define the main concepts used in the study: "gender", "masculinity".

The term "gender" was first introduced in 1986 by Joan Wallach Scott, a researcher and an educator, who defined it as "... an integral element of social relations, which is based on the conscious differences between the sexes" [13]. In later works "gender" is regarded as a "complex mechanism", a "technology", or a "gender system" that determines the subject of normativity in society; includes the cultural symbols developed by society in the course of 
its development, the laws and social institutions that regulate the life of a person and society, as well as self-identification of the individual.

The Collins Dictionary of Sociology interprets "masculinity" as characteristic features inherent in the male sex. From the point of view of the historical study "masculinity" is the code of conduct, heroism, strength, and the focus on the general character of a man ..." [14].

Psychology considers masculinity to be a set of qualities of the male personality, expressed in "... the ability to act decisively and reasonably in a complex dangerous situation, to control impulses, to overcome possible feelings of fear and uncertainty, to make every effort to achieve the goal" [15].

Focusing on the "masculinity" concept given above and taking into account the fact that the initial foundations of this moral and psychological quality are laid at the stage of early and pre-school childhood, we conducted our study to prove that the special forms, methods and conditions used in working with children of senior pre-school age get positive results.

The experiment was carried out in the municipal budget pre-school educational institution № 63 “Zhemchuzhinka" ("Pearl”) in Naberezhnye Chelny, the Republic of Tatarstan (teacher - Z.M. Tolstopyatova). The study involved the children of two senior groups of the pre-school educational organization (experimental and control groups). There were 33 boys among them.

Firstly, the level of formation of the moral and psychological quality - masculinity was studied in 6-year-old boys. The following criteria were used: 1) availability and the current level of development of ideas about masculinity on the following scales: a) external conformity, b) physical training, c) responsibility, d) activity, e) courage; 2) the formation of motives to correspond to the ideas of masculinity in gender behavior; 3) the gender identity manifestation.

In addition, the indicators of three-level masculinity formation (high, medium, and low) were developed. After the appropriate diagnostic work had been done, the results were handled and the following data were obtained: the experimental group comprised $6 \%$ of the boys with a high level of masculinity, while the control one $-7 \%$; there were $19 \%$ of the boys with an average level in the experimental group, while in the control group there were $16 \%$ and $75 \%$ of the boys in the experimental group had a low level, while in the control group $77 \%$ had the same level.

The results obtained in the course of the study spoke in favor of organizing the special activities aimed at teaching boys of senior pre-school age the masculinity, which would involve three-component work with the following content and semantic content:

1. The cognitive component was designed to provide the preschoolers with the ideas about their belonging to a certain gender, about the main masculine and feminine qualities, and about the characteristics of human behavior depending on gender differences.

2. The emotional and personality component involved forming the motives to meet the standard of masculinity, men's manifestations and preferences.

3. The behavioral component was a reflection of the acquired ideas about gender-role behavior in interaction with representatives of one's own and the opposite sex.

To conduct the study (according to the above components), a long-term plan with specially selected forms, methods and conditions was developed. The plan included: 1) different types of activities (cognitive and productive activity, games, arts, labor, reading) aimed at supporting and developing the child's gender identity; 2) specially selected forms, methods and conditions for working with preschoolers to provide them with the ideas about masculinity as a moral and psychological quality; 3) family education to cope with the problems of children's gender identification. The sample of the plan aimed at teaching boys the masculinity is given below [Table 1]. 
Table 1. Sample of Plan for Teaching Boys the Masculinity.

\begin{tabular}{|c|c|c|}
\hline $\begin{array}{l}\text { Type of } \\
\text { Activity }\end{array}$ & $\begin{array}{l}\text { Content, Forms and Methods of Working with } \\
\text { Children }\end{array}$ & $\begin{array}{l}\text { Content and Forms of } \\
\text { Working with Parents }\end{array}$ \\
\hline $\begin{array}{l}\text { Cognitive } \\
\text { activity }\end{array}$ & $\begin{array}{l}\text { Classes on the following topics: "We are Boys", "We } \\
\text { are Girls", "My Body", "My Games and Favorite } \\
\text { Activities" } \\
\text { Objectives: } \\
\text { - Forming the basic ideas about oneself as a } \\
\text { biopsychosocial being: boys and girls are similar in } \\
\text { appearance; they have legs, arms, and heads. On the } \\
\text { head there are ears, a nose, a mouth, and a tongue. } \\
\text { - Developing curiosity and cognitive interests, a caring } \\
\text { attitude towards the body. }\end{array}$ & $\begin{array}{l}\text { Parent-teacher meeting; } \\
\text { teacher's report on } \\
\text { "Forming the Ideas about } \\
\text { Masculinity in Boys" } \\
\text { Express survey } \\
\text { Wall board "Magic } \\
\text { Flower of Wisdom" with } \\
\text { parents' statements about } \\
\text { how to raise boys }\end{array}$ \\
\hline & $\begin{array}{l}\text { Didactic games ("Who Wears This or That?", "Make } \\
\text { up a Portrait", "Why do we Like Boys and Girls?", } \\
\text { "Names", etc.) } \\
\text { Objectives: } \\
\text { - Summarizing the basic ideas. } \\
\text { - Forming the adequate individual's identification with } \\
\text { other people. }\end{array}$ & $\begin{array}{l}\text { Consultation with parents } \\
\text { on "Organizing the } \\
\text { Conditions for Games in } \\
\text { the Family" } \\
\text { Assistance with choosing } \\
\text { didactic games for boys }\end{array}$ \\
\hline Games & $\begin{array}{l}\text { Role-playing "Journey" } \\
\text { Objectives: } \\
\text { - Summarizing the children's ideas about the jobs of } \\
\text { adults. } \\
\text { - Teaching a respectful attitude to the jobs of adults. } \\
\text { Role-playing "Helicopter Pilots". } \\
\text { Objectives: } \\
\text { - Forming the ideas about masculinity, courage, } \\
\text { endurance when discussing the profession of helicopter } \\
\text { pilots. } \\
\text { - Teaching the strong-willed qualities and humane } \\
\text { feelings that are necessary when overcoming } \\
\text { difficulties and saving people. }\end{array}$ & $\begin{array}{l}\text { Making attributes and } \\
\text { costumes for the role- } \\
\text { play } \\
\text { Conversation with } \\
\text { fathers about the role- } \\
\text { plays for boys, about } \\
\text { creating the atmosphere } \\
\text { of mutual support in the } \\
\text { family and the common } \\
\text { interests of parents and } \\
\text { children }\end{array}$ \\
\hline Arts & $\begin{array}{l}\text { Drawing “My Friend's Portrait" } \\
\text { Objectives: } \\
\text { - Teaching to draw a person's face. }\end{array}$ & $\begin{array}{l}\text { Exhibition of children's } \\
\text { drawings } \\
\text { Photo exhibition "A } \\
\text { Friendly family" }\end{array}$ \\
\hline Reading & $\begin{array}{l}\text { Reading the poem "If I were a Girl ..." written by E. } \\
\text { Uspensky. } \\
\text { Discussing the poem. } \\
\text { Objectives: } \\
\text { - Forming the ideas about the family roles, about the } \\
\text { responsibilities of family members. } \\
\text { Reading the stories "On the Ice Floe", "Mail" written } \\
\text { by B. Zhitkov; "Helicopter Pilots" by B. Bakharevsky. } \\
\text { Discussing the stories. } \\
\text { Objectives: } \\
\text { - Forming a collective image of a courageous hero } \\
\text { having courage, strength, and the ability to protect the } \\
\text { weak. } \\
\text { - Motivating the boys to do various types of men's } \\
\text { work. }\end{array}$ & $\begin{array}{l}\text { Attending and enrolling } \\
\text { in the children's library } \\
\text { Consultation on } \\
\text { "Favorite Books of } \\
\text { Boys" }\end{array}$ \\
\hline Labor & $\begin{array}{l}\text { Manual labor. Making a cardboard pilot's helmet. } \\
\text { Objectives: - Forming the ideas about men's } \\
\text { professions and about masculinity manifestation in the } \\
\text { profession of a helicopter pilot. }\end{array}$ & $\begin{array}{l}\text { Joint activity of children } \\
\text { and parents when making } \\
\text { a cardboard pilot's } \\
\text { helmet. }\end{array}$ \\
\hline
\end{tabular}


The work that was aimed at forming the pre-school children's ideas (cognitive component) about their belonging to a certain gender, about the main masculine and feminine qualities, and about people's behavior depending on the gender differences involved a number of classes on the following topics: "We are Boys", "We are Girls", "My Body", "My Games and Favorite Activities". The classes allowed the children to learn the ideas about external characteristics, features of human behavior, depending on the gender differences. At the classes the children learnt that boys and girls have a lot in common (heads, bodies, arms, legs, etc.), but they also have distinctive features (for example, Azat said that the main difference was that they wore different clothes, Kostya pointed out that they had different hair lengths, etc.). The children learnt that both boys and girls were different not only in appearance, but they also experienced different feelings: girls were tender, their feelings were brighter, while boys were strong, tried to restrain their feelings, rarely showed fear or cry. The children got acquainted with different jobs that were traditionally done by men (rescuers, sailors, pilots) and women (teachers, nurses, dressmakers), with men's and women's hobbies.

At the Arts classes, children drew male and female portraits, acquired new knowledge, learnt to see the differences between boys and girls, and showed the characteristic features of men and women in the portraits of their mothers, fathers, in a portrait of a little princess, or in a portrait of an epic hero. The work started in the classroom and then the children finished working at home. Many children brought drawings made together with their parents (a portrait of mother in a smart dress, a portrait of grandfather with a mustache, etc.). The group organized an exhibition of drawings. The children were happy to speak about the people they had drawn and to discuss their works.

To generalize the gained knowledge, the children were offered some didactic games ("Who Wears This or That?", "Make up a Portrait", "Dress Properly", "Why do we Like Boys and Girls?", "Names", etc.). The games and competitiveness created an emotionally positive atmosphere for communicating and learning. When using the didactic games, a number of conditions were met: the games were selected according to the main parameters of gender education; the games always satisfied the age characteristics of pre-school children; any game was adequate for a certain stage of pre-school childhood.

Reading was widely used in the work done. Reading the fairy tales ("The Frog Princess", "The Scarlet Flower", etc.), the stories ("Through the Blizzard" by I. Vinokurov, "On the Ice Floe" by B. Zhitkov, "The Story of an Unknown Hero" by S. Marshak, etc.) helped to create a collective image of the male hero. When discussing the books, the focus was on such qualities as courage and strength to protect the weak and to do men's work.

Another interesting way of our work was composing a story or a fairy tale. In the stories composed by the children the heroes were their fathers and elder brothers. The children learnt for the first time that the heroes' mood could be "drawn". To teach them to do that the class on "Being Acquainted with Emotions" was taken, where the children learnt to recognize the mood by various signs: the facial expressions, the voice with different intonation, and the graphic image of emotions. In their drawings the children tried to convey the inner state of the heroes (the boys drew some male heroes, the girls - some female characters, and vice versa).

We placed importance on the books creating the image of the family (P. Mumin "Our Family is a Working One", E. Serova "Dad at Home"). When discussing the books, the children were led to the conclusion that a happy family is a friendly family, where everyone takes care of each other, where children help their parents. When discussing the story "How Vitya Cured his Mother" written by V. Donnikova, the children were asked, "Why did his mother feel better though Vitya did not take care of her very skillfully?" Nail and the other children replied that Vitya's mother was happy that she had a good son, who loved her and took care of her. During the conversation the children also remembered their good things 
when they helped their mothers. Those conversations significantly developed the children's ideas about masculinity and femininity, enriched their impressions, and helped to lay on plenty activities for the children of both sexes.

The role-plays successfully facilitated forming the motives in pre-school children (emotional and personal component) to meet the standard of masculinity, the male manifestations and preferences. The boys' favorite role-plays were those that helped them to learn new things about military men's professions. Also, the boys participated with pleasure in the role-plays in which they behaved in particular situations, for example, "Helicopter Pilots". Thus, the boys learnt how pilots fly helicopters: how they take off or land. To develop the role-plays, a lot of preliminary work was done. First, we read the stories "Helicopter Pilots" written by V.A. Bakharevsky and "On the Ice Floe" by B. Zhitkov. When discussing the stories, the children tried to explain what "courage" and "strength" are, and why these qualities are especially important when doing difficult or dangerous work. In addition, we analyzed the situations on "Rescue of People in the Mountains", "Children Got Sick", etc. Then we asked Azat's mother and Kostya's mother to sew pilots' overalls. At Manual Labor classes the children made cardboard pilots' helmets. Alina's father was asked to tell the boys about different types of flying machines. After that conversation, we read the book "On Land, in the Sky, and at Sea" written by K. Belyaev and G. Markusha. Information and communication technologies were widely used to learn more about flying machines. That significantly improved the emotional and personal component quality of the education. The children learnt some new information about the helicopter models, their distinctive features, and they independently drew conclusions about the functions of those types of transport.

To overcome the existing disunity between the boys and girls, the children were involved in the role-play "Auto Repair". To role-play a gas station was made from improvised things; a cafe was made next to it, as well as a playground for children. The roles were distributed among the children: the boys played the roles of drivers, the girls the roles of mothers, waitresses in the cafe, teachers - on the playground. The parents were asked to watch the film "The Queen of the Gas Station" with their children at home to gain new information and impressions.

In the course of implementing the activity component the acquired gender concepts were actualized in the game "Secret Meetings" based on the method that was developed by Sh.A. Amonashvili [16]. It was adapted to the needs of senior pre-school children. The game was aimed at actualizing the acquired ideas about masculinity in the real behavior of boys and in the daily communication of children of both sexes. At the beginning of the game, the teacher asked the boys if they agreed to establish a secret society of true men. Then the teacher explained the rules of the secret society: true men do not offend girls, always let girls go ahead, take on more difficult "male" work, etc. To teach the girls to appreciate the boys' attention and to foster a sense of taking care, a secret society of true women was established, but with its own rules. The game proved to be an effective way to teach the boys and it lasted for a long time. The interest in that game was explained by the fact that the rules were formulated in a playful way, using an element of mystery; the concluded agreement to keep the society secret helped the boys to be self-controlled and strong-willed.

In our opinion the properly organized activities in the pre-school educational organization resulted in the changes in children's manifesting their gender stability. The behavioral responses of the boys and girls, their self-perception were consistent with the parameters of social and emotional development according to their gender identification and our gender expectations. The observed changes in the behavior of the boys and their ideas about masculinity led to conclusion that children's activities are a primary condition for gender education at a pre-school age. 
Another important condition for gender education was creating a functional subjectdeveloping environment in the pre-school organization. That environment was considered to be both a condition for boys' activity (mental, physical, etc.), and the basis for independent activity of children, taking into account their gender characteristics. The subject-developing environment involved the special play areas for the boys. The principal element of the subject-developing environment for boys became learning minienvironments to develop helpful men's skills ("Garage", "Auto Repair", and "Airfield"). When organizing the role-plays, various toys were used (figurative, transport, sports, etc.) to perform various social roles. At the same time, the children were offered a number of action-schemes that contained the cultural standards of male and female behavior and different cards with the symbols of the socially valuable qualities such as kindness, courage, honesty, and bravery.

The issues of organizing some space for playing at home were discussed with the boys' parents. The parents were told that developing the boys' gender identity was possible only in the environment where children could show their individual characteristics, as well as their gender characteristics.

The work done allowed us to get positive results. There were obvious changes in the boys as they became self-confident, desirous of being strong, protecting the weak, and taking care of the girls. Thus, at a senior pre-school age child realize the sexual gender identity and that coincides with greater sexual differentiation of their behavior and attitudes.

\section{Discussion}

The study has confirmed the conclusions contained in other information sources about the gender characteristics of pre-school-age boys (V. N. Klipinina-Litovchenko [2], M. A. Radzivilova [9], N. E. Tatarintseva [10], A. M. Shchetinina [11], etc.). Sharing the points of view of the authors, we agree that boys are more likely to study the environment, learn more about new subjects; they tend towards dominance and taking risks. They are active and more often aggressive than girls. At a senior pre-school age child have the initial forms of friendly feelings. However, boys' feelings are less long-lasting in comparison with girls' ones. In their relationships, boys always want to know the answer to the question: Who is the leader? Boys' games involve moving in space and working in a team. There are two opposing sides ("enemies-heroes") in their typical games. While playing

boys occupy all the space available. If there is not enough space in the horizontal area, then they occupy the vertical one: they climb the stairs, the trees, etc. We also agree that boys are more interested in different things. As we have found, their interests are broader and go beyond their close surrounding (space, travel, adventure). The sphere of boys' interests is connected with their high motor and cognitive activity, with the need for transformations. Hence, they are interested in various mechanisms and devices. When studying a toy or a thing boys often want to know how it works. Having broken a toy, boys again take the opportunity to study its parts or use it for some other purposes; girls simply throw it aside as a useless thing.

However, we cannot agree with the statements of some authors [17], who consider adolescence to be the most important period of gender-role socialization, without taking into account the early and preschool stages of childhood. The study has proved it is a preschool age that is a significant and, one might say, sensitive period of gender identification, when a child does everything for the first time, discovering the world. The study has also found that taking a gender approach helps to understand the gender aspects when teaching boys at the stage of pre-school childhood. Conversely, a gender approach to teaching the preschoolers is helpful when understanding the issues of gender identification and socialization of preschool children. 


\section{Conclusions}

The results of the experiment confirmed the hypothesis and allowed us to formulate the following findings:

1. Masculinity as a moral and psychological quality of a male is a generalizing characteristic of a personality. The "masculinity" concept involves such qualities as strength, courage, self-control, determination, honesty and justice. Masculinity cannot be formed without taking into account the psychological specifics of gender as it is developed when imitating.

2. The process of teaching boys the qualities of masculinity will be effective if the following conditions are met: creating a gender-functional subject-developing environment; involving children in different types of activities and communication that reflect gender standards; improving the gender competence of teachers and parents.

The work done at the present stage allows us to state that the purposeful process of pedagogical support of a preschooler that involves accumulating the gender experience should be continued. This intention makes it possible to set new objectives to gain broader experience of children's performing the gender roles and identifying themselves as representatives of their own sex at the stage of early childhood.

\section{References}

1. V. Vdovyuk, S. Rykov, Higher education in Russia 4, 110-117 (2001)

2. T.K. Antonova, Actual Problems of Pedagogy: materials of the I International Scientific Conference (Molodoy Uchyony Publishing House, Chita, 2011)

3. N.G. Chernyshevsky, Complete Works (Goslitizdat, Moscow, 1939)

4. V.S. Solovyov, Russia and the Universal Church (Put, Moscow, 1911)

5. N.A. Berdyaev, Eros and Personality: The Philosophy of Sex and Love (Prometey, Moscow, 1989)

6. S.M. Burn, A.Z. Ward, Psychology of Men and Masculinity 6, 254-263 (2005)

7. J.-L. Flandrin, Le sexe et Occident: évolution des attitudes et des comportements (Éditions du Seuil, Paris, 1981)

8. E.E. Maccoby, C.N. Jacklin, The psychology of sex differences (Stanford University Press, Stanford, CA, 1974)

9. M.A. Radzivilova, Fundamental Research 4-2, 453-456 (2013)

10. N.E. Tatarintseva, Pre-school education 3, 28-33 (2009)

11. A.M. Shchetinina, O.I. Ivanova, Gender Role Development of 5-7-year-old Children (Sphera, Moscow, 2010)

12. E.N. Kamenskaya, Gender Approach in Pedagogy (Rostov-on-Don, 2006)

13. J.W. Scott, American Historical Review 91(5), 1053-1075 (1986)

14. D. Jary, J. Jary, Collins Dictionary of Sociology, Volume 1 (Veche, AST, Moscow, 1999)

15. L.A. Karpenko et al., Brief Dictionary of Psychology (Politizdat, Moscow, 1985)

16. Sh.A. Amonashvili, Hello, children! (Prosveshcheniye, Moscow, 1983)

17. I.A. Kurochkina, V.V. Puzyryov, Pedagogical Education in Russia 9, 157-162 (2019) 